\title{
Moth and mosquito orientation to odor sources: how the structure of the odor plume modulates navigation
}

\author{
Ring T Cardé \\ From 1st International Workshop on Odor Spaces \\ Hannover, Germany. 4-7 September 2013
}

Finding downwind sources of odor first requires responders to contact the odor plume. Whether flying insects have optimal strategies to minimize either time to contact or energy expended en route is poorly understood and perhaps their heading with respect to contemporaneous wind flow is simply random.

Once the plume is sensed, flying insects track along such plumes by heading upwind as long as contact with the odor is maintained. Their heading with respect to wind flow is gauged by visual feedback, a mechanism termed optomotor anemotaxis. If the insect is heading due upwind, image flow is front-to-rear; if the insect is headed at an angle to wind flow, it also experiences some transverse image flow. Simply flying upwind along the plume, however, does not routinely lead to source location. Large odor-free gaps caused by turbulent diffusion and by objects in the environment require strategies for re- contacting the plume, as seen in the casting behavior of moths. Another challenge to successful plume tracking is imposed by changes in wind direction and velocity; these can misalign the path along the plume and the instantaneous direction upwind, also resulting in casting maneuvers. Within the plume the rate of encountering odor filaments seems to dictate a moth's heading, with rates $>5 \mathrm{~Hz}$ promoting a straightened-out upwind course

Female mosquitoes orientating to prospective hosts and male moths orienting to a calling female face similar navigational challenges, but, compared to a moth signal, the odor source for mosquitoes is generally much larger and produces a complex odor bouquet. Aedes aegypti, a highly anthropophilic mosquito, orients upwind to carbon dioxide and to human skin odor, which unlike moth pheromones is a complex and somewhat variable blend

Department of Entomology, University of California Riverside, CA 92521, USA of hundreds of constituents. Females orient well to either carbon dioxide or skin odor, but the spatial presentation and interaction of these two cues influences the mosquito's moment-to-moment maneuvers and odor threshold.

Published: 16 April 2014

doi:10.1186/2044-7248-3-S1-027

Cite this article as: Cardé: Moth and mosquito orientation to odor sources: how the structure of the odor plume modulates navigation. Flavour 2014 3(Suppl 1):027.

Submit your next manuscript to BioMed Central and take full advantage of:

- Convenient online submission

- Thorough peer review

- No space constraints or color figure charges

- Immediate publication on acceptance

- Inclusion in PubMed, CAS, Scopus and Google Scholar

- Research which is freely available for redistribution 